\title{
VERBAL LANGUAGE SPONTANEOUS RECOVERY AFTER ISCHEMIC STROKE
}

\author{
Gabriela Camargo Remesso', Ana Lúcia de Magalhães Leal Chiappetta', Alexandre Santos Aguiar², \\ Márcia Maiumi Fukujima ${ }^{3}$, Gilmar Fernandes do Prado 3
}

\begin{abstract}
Objective: To analyze the spontaneous recovery of the verbal language on patients who have had an ischemic stroke. Method: Retrospective analysis of 513 medical records. We characterize referring aspects for data identification, language deficit, spontaneous recovery and speech therapy. Results: The average age was 62.2 years old $(S D= \pm 12.3)$, the average time of academic experience was 4.5 years $(S D= \pm 3.9), 245(47.7 \%)$ patients presented language disturbance, 166 (54.0\%) presented spontaneous recovery, from which 145 (47.2\%) had expression deficit ( $\mathrm{p}=0.001) ; 12(3.9 \%)$ had comprehension deficit and $9(2.9 \%)$ had both expression and comprehension deficit. Speech therapy was carried with 15 patients $(4.8 \%)(p=0.001)$. Conclusion: The verbal language spontaneous recovery occurred in most of the patients being taken care of at the stroke out clinic, and expression disturbance was the most identified alteration. As expected, the left hemisphere was associated with the deficit and smoking and pregressive stroke were the language alteration primary associated factors.
\end{abstract}

KEY WORDS: aphasia, language, stroke, neuronal plasticity.

\section{Recuperação espontânea da linguagem verbal após acidente cerebrovascular isquêmico}

Resumo - Objetivo: Analisar a recuperação espontânea da linguagem verbal em pacientes que sofreram acidente cerebrovascular isquêmico (AVCl). Método: Análise retrospectiva de 513 prontuários. Caracterizamos aspectos referentes aos dados de identificação, déficit de linguagem, recuperação espontânea, realização de tratamento fonoaudiológico. Resultados: A média de idade foi 62,2 anos ( $D P= \pm 12,3$ ), o nivel de escolaridade teve média de 4,5 anos (DP= $\pm 3,9), 245$ (47,7\%) pacientes apresentaram alteração de linguagem, 166 (54,0\%) apresentaram recuperação espontânea sendo $145(47,2 \%)$ do déficit de expressão ( $p=0,001), 12$ (3,9\%) de compreensão e 9 $(2,9 \%)$ misto. A realização de tratamento fonoaudiológico foi encontrada em $15(4,8 \%)(p=0,001)$. Conclusão: A recuperação espontânea da linguagem verbal ocorreu na maioria dos pacientes atendidos no ambulatório de $\mathrm{AVCl}$ e a alteração mais encontrada foi de expressão. Como esperado o hemisfério esquerdo associou-se ao déficit, sendo o tabagismo e AVC pregresso fatores preditores de alteração de linguagem.

PALAVRAS-CHAVE: afasia, linguagem, acidente cerebrovascular, plasticidade neuronal.

Cerebrovascular disease is responsible for one third of adult's deaths in Brazil, about 125,000 Brazilians suffer a new stroke or present a new recurrent condition every year. It occurs more frequently on individuals above 85 years of age and the occurrence on people below 45 years of age comprises around $10 \%$ to $20 \%$ of the cases $^{1-4}$. Among the most frequent stroke aftermath, there is the aphasia, characterized by language disturbance that causes a loss of expression and/or oral and written comprehension, varying from type, level and lesion extension. It occurs in $20 \%$ to $30 \%$ of the stroke cases and it brings the patient and his caregiver great suffering, resulting from the alterations that affect the communication and life style $e^{5,6}$. The aphasias are sorted in expressive, with lesion on the cortical and / or subcortical frontal region and emission deficit higher than comprehension (Broca, conduction and transcortical motor); receptive, with lesion on the cortical and / or subcortical temporoparietal region and the comprehension deficit is higher than the emission (Wernicke, transcortical sensorial and anomic); and a mix between expression and comprehension being compromised (mixed transcortical, and global) ${ }^{7,8}$. A re-

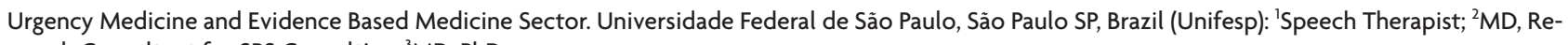
search Consultant for SPS Consulting; ${ }^{3} \mathrm{MD}$, PhD.

Received 22 September 2008, received in final form 18 June 2009. Accepted 2 July 2009.

Dra. Gabriela Camargo Remesso - Av. Leôncio de Magalhães 1004 / 82 - 02040-001 São Paulo SP - Brasil. 
search showed that the Broca aphasia recovery involves the reorganization between the superior temporal gyrus, putamen and lower inferior temporal gyrus, while Wernicke aphasia involves the reorganization of temporal gyrus, supramarginal gyrus and lower parietal lobe?.

Aphasic patients who suffered lesion in the brain's language zones present a certain level of spontaneous recovery in almost all cases, due to neuronal plasticity, defined as any changes on cortical regions such as a the functional or morphological answer to environmental alterations or lesions ${ }^{10,11}$. Studies have shown that the linguistic capacities recovery occurs faster on the early months after the stroke due to neuronal plasticity and also because few improvements are obtained after one year post stroke ${ }^{12,13}$. However, it is not established the time for verbal language spontaneous recovery after the stroke.

The objective of this study was to analyze the verbal language spontaneous recovery on patients who have had stroke and compare them with the ones who received speech treatment.

\section{METHOD}

A retrospective analysis of 513 medical records of adult patients with stroke diagnosis was done between the period of November, 1998 and December, 2004. There were 258 men (50.3\%) and 255 women (49.7\%), taken care as outpatient, and they were part of a clinical trial (TEEAS - transoesophageal echocardiography and aspirin doses for stroke) approved by the Unifesp Ethical and Research Committee, and informed consent was obtained. The data analyses were based on a retrospective coorte model which endpoint was loss of language.

The study consisted in collecting demographic and clinical data relating to identity (gender, age and education), risk factors (smoking, alcoholism, previous stroke, hypertension, diabetes mellitus, coronary artery disease and body mass index), followup time at the clinic, language deficit (understanding, expression or mixed), language deficit intensity (mild or severe), presence of spontaneous recovery and its timing, implementation of speech treatment and time of recovery with therapy. It was also examined the presence of recurrence of stroke with impairment of language and death. The injury topography diagnosed with neuropsychological examination, by computerized tomography (CT) or magnetic resonance imaging (MRI) was classified as in the right hemisphere, left hemisphere, brainstem and multiple.

The language was considered normal if there were fluent speech, expression and understanding without amendments. The loss of language was ranked intense when fluent talk did not occur, oral expression and speech comprehension was compromised in various intensities, aural paraphasias and/or phonological and/or semantic, speech and writing suppression, stereotypy, agrammatism, logorrhea, echolalia and anomie, mild when oral expression was slightly impaired, no fluent speech with intelligibility preserved, there could be minor changes as aural para-
Table 1. Demographic data, risk factors, topography of injury and death.

\begin{tabular}{|c|c|c|}
\hline & $\begin{array}{l}\text { Without deficit } \\
n=268\end{array}$ & $\begin{array}{c}\text { With deficit } \\
n=245\end{array}$ \\
\hline Age (average) & 63.2 & 62.1 \\
\hline \multicolumn{3}{|l|}{ Gender n (\%) } \\
\hline Male & $127(46.5 \%)$ & $131(53.5 \%)$ \\
\hline Female & $141(53.5 \%)$ & $114(46.5 \%)$ \\
\hline \multicolumn{3}{|l|}{ Schooling $\mathrm{n}(\%)$} \\
\hline $0-4$ years & $177(66.0 \%)$ & $168(68.6 \%)$ \\
\hline $5-8$ years & $49(18.3 \%)$ & 37 (15.1\%) \\
\hline $9-12$ years & 32 (11.9\%) & $26(10.6 \%)$ \\
\hline$>12$ years & $9(3.4 \%)$ & $13(5.3 \%)$ \\
\hline \multicolumn{3}{|l|}{ Risk factors n (\%) } \\
\hline Smoking & 79 (29.5\%) & $107(43.7 \%)$ \\
\hline Alcoholism & $35(13.1 \%)$ & 45 (18.4\%) \\
\hline Previous stroke & $48(19.7 \%)$ & $70(28.6 \%)$ \\
\hline Hypertension & $214(79.9 \%)$ & $200(81.6 \%)$ \\
\hline Diabetes mellitus & $64(23.9 \%)$ & $79(32.2 \%)$ \\
\hline Coronary disease & 41 (15.3\%) & $28(11.4 \%)$ \\
\hline Body mass index $\geq 30$ & $51(19.0 \%)$ & $33(13.5 \%)$ \\
\hline \multicolumn{3}{|l|}{ Lesion topography n (\%) } \\
\hline Right hemisphere & $132(25.8 \%)$ & $82(15.9 \%)$ \\
\hline Left hemisphere & $117(22.8 \%)$ & $144(28.1 \%)$ \\
\hline Brainstem & $12(2.4 \%)$ & $8(1.5 \%)$ \\
\hline Multiple & $10(1.9 \%)$ & $8(1.6 \%)$ \\
\hline Death n (\%) & $17(6.3 \%)$ & $30(12.2 \%)$ \\
\hline
\end{tabular}

phasias and / or phonological and / or semantic, speech and writing suppression, stereotype, agrammatism, logorrhea, echolalia and anomy ${ }^{7,8}$.

This research has been approved by the Research Ethics Committee on Research, the CEFAC - Health and Education, under paragraph 214/06. We used the chi-square test for comparisons between proportions of categorical variables and logistic regression to identify predictive factors for disorder of language after the ischemic stroke. It was considered $\mathrm{p} \leq 0.05$ significant.

\section{RESULTS}

We analyzed, therefore, 513 records of patients with ischemic stroke. Regarding the identification data, our sample consisted of 258 men (50.3\%) and 255 women (49.7\%), age ranging from 26 to 92 years (average 62.2 years $\mathrm{SD}= \pm 12.3)$. Regarding time of academic experience two patients were excluded $(0.04 \%)$, as the information was incomplete, and ranged from 0 to 27 years of age with an average of 4.5 years of academic experience $(S D= \pm 3.9)$. The range of 0 to 4 years represented by $67.5 \%$ of the patients, 5 to 8 years represented by $16.8 \%, 9$ to 12 years represented by $11.4 \%$ and over 12 years represented by $4.3 \%$ (Table 1).

The risk factors considered were smoking, alcoholism, previous strokes, diabetes mellitus, high blood pressure 
Table 2. Deficit of language as for the type and degree.

\begin{tabular}{lcccc}
\hline Type / Level & Mild $\mathrm{n}(\%)$ & Intense $\mathrm{n}(\%)$ & Total $\mathrm{n}$ & $\mathrm{p}$ \\
\hline Expression & $237(99.2 \%)$ & $2(0.8 \%)$ & 239 & 0.001 \\
Understanding & $33(89.2 \%)$ & $4(10.8 \%)$ & 37 & 0.001 \\
Mixed & $31(100 \%)$ & $0(0 \%)$ & 31 & 0.001 \\
\hline
\end{tabular}

Chi-square Test, $\alpha<0.05$

and body mass index (BMI) as in Table 1. The monitoring timing at the clinic ranged from 1 to 74 months with an average of $23.4(\mathrm{SD}= \pm 14.7)$.

The neurological lesion topography diagnosed by CT or MRI was more frequent in the left hemisphere $(50.9 \%)$ as in Table 1, and presented relative risk of 2.11 with a confidence interval of $95 \%$ ranging from 1.48 to 3.01 . And only $8.9 \%$ of the patients deceased.

Changes in language were found in 245 (47.7\%) patients, and the expression deficit occurred in most patients. The mild intensity was more frequent than the intense level of deficit in terms of language, expression, understanding and a mix, with statistical significance (Table 2).

The verbal language spontaneous recovery was more significant in patients with expression deficit (Table 3). The timing of spontaneous recovery varied from 1 to 58 months with an average of 6.05 months $(S D= \pm 7.9)$.

The completion of speech treatment was found in $4.8 \%$ of the patients and had no statistical significance in recovery. The time for recovery with speech treatment ranged from 1 to 15 months with an average of 3.5 months ( $S D= \pm 5.3)$, as in Table 4.

The presence of stroke or transient intra-axial attacks was found in $42(8.2 \%)$ patients, and amendment of language appeared in $22(2.3 \%)$ patients (kappa $=0.019$, $p=0.447)$. There was no association between change of language and recurrence of stroke.

There were factors as predictors for change of language: smoking, strokes and pre lesion in the left hemisphere $(p=0.001)$.

\section{DISCUSSION}

Language spontaneous recovery studies are scarce, and in Brazil there are many patients who have no reach for speech treatment to maximize the language recovery, and rely only on neuroplasticity and the spontaneous recovery itself. Based on the results there was no difference between men and women, agreeing with a research in which the sample showed up as homogeneous as ours ${ }^{14}$ and disagreeing with a study that showed a non homogeneous sample, with a prevalence of $66.6 \%$ of women ${ }^{15}$.

As for the age, the sample showed an average age of 62 , disagreeing with other studies that showed aphasic patients with differences regarding the averages showed in samples ${ }^{13-16}$.
Table 3. Spontaneous recovery.

\begin{tabular}{lccc}
\hline Spontaneous recovery & $\mathrm{n}(\%)$ & $\mathrm{n}(\%)$ & $\mathrm{p}$ \\
\hline Expression & $145(47.2 \%)$ & $94(30.6 \%)$ & 0.001 \\
Understanding & $12(3.9 \%)$ & $25(8.2)$ & 0.629 \\
Mixed & $9(2.9 \%)$ & $22(7.2 \%)$ & 0.993 \\
Total & $166(54 \%)$ & $141(46 \%)$ & \\
\hline
\end{tabular}

Chi-square Test

Table 4. Speech treatment Implementation .

\begin{tabular}{lcc}
\hline Recovery & $\mathrm{n}(\%)$ & $\mathrm{p}$ \\
\hline Full recovery & $7(2.2 \%)$ & 0.001 \\
Partial recovery & $3(0.9 \%)$ & 0.019 \\
No recovery & $5(1.7 \%)$ & - \\
Total & $15(4.8 \%)$ & \\
\hline
\end{tabular}

Our sample was formed by a population who had low education level, agreeing with researches that had similar averages, showing that the Brazilian public service users present a low rate of schooling ${ }^{14,16,17}$.

The low educational level and low socioeconomic status may influence the severity of aphasia in the early stage, and the illiterate present visuoperceptual difficulties hampering the intensity of recovery that may be low for people on that group ${ }^{16,18}$. We believe that the low educational level of our patients may have influenced the recovery time.

In relation to risk factors examined, smoking and previous stroke were predictors for the amendment in language. The values found are similar to other studies regarding stroke risk factors ${ }^{2,4,19}$, and agrees with the study on smoking, showing that normal individuals with no neurological lesion, that make use of cigarette show major changes in memory work and language understanding ${ }^{20}$.

Most patients had the expression deficit, disagreeing from Bakheit colleagues that in their aphasic samples presented a higher number of patients with understanding disturbs $(40.3 \%)$ than expression disturbs $(37.4 \%)^{5}$.

The spontaneous recovery occurred in $54 \%$ of the patients with an average recovery time of six months, ranging from 1 to 58 months, agreeing with conclusions of Mansur and colleagues who recorded the spontaneous 
recovery in the first six months after injury and after that, small changes occurred ${ }^{14,15}$.

Researches show that the recovery is a complex process that depends on neuropsychological processes and environmental factors. The reorganization processes begin soon after the injury ${ }^{23}$. This cortical area reorganization related to language (temporal chain pre-existing frontal), consists in the activation of not injured areas in both hemispheres, but particularly the right hemisphere, that may be decisive for the recovery of the language function ${ }^{11,22-25}$.

In this sample only 15 patients were under speech treatment, different from what happens in the United States, where most of the patients who have language disturbs achieve specific treatment to improve the maximum recovery ${ }^{26}$. In Brazil we still have difficulties in referring how important the speech treatment is for the reduction of recovery time. Our treated patients had spontaneous recovery in almost half the time of untreated ones, suggesting that the speech treatment maximizes recovery by promoting reorganization of cortical structures, according to the findings in studies that show speech and language therapy improves the patient's ability to use verbal skills along with non-verbal means to achieve an adequate situation of the social communication, and has beneficial effect when started early and with intense training ${ }^{5,11,13}$.

In conclusion, the verbal language spontaneous recovery occurred in most patients at the outpatient ischemic stroke clinic with an average time of 6 months, and the language alteration most presented was in language expression. The timing of language recovery with speech treatment was almost half of the time in those who had spontaneous recovery, showing the importance of correct diagnosis and referral.

\section{REFERENCES}

1. Radanovic M. Características do atendimento de pacientes com acidente vascular cerebral em hospital secundário. Arq Neuropsiquiatr 2000;58:99-106.

2. Yamashita LF, Fukujima MM, Granitoff N, Prado GF. Paciente com acidente vascular cerebral isquêmico já é atendido com mais rapidez no Hospital São Paulo. Arq Neuropsiquiatr 2004;62:96-102.

3. Fukujima MM. Acidente vascular cerebral. In: Ortiz KZ, organizador. Distúrbios neurológicos adquiridos: linguagem e cognição. Barueri: Manole, 2005:34-46.

4. Buksman S. Acidente vascular encefálico. Revista da SOCERJ 2004;73-80.
5. Bakheit AMO, Carrington S, Griffiths S, Searle K. High scores on the Western Aphasia Battery correlate with good functional communication skills (as measured with the Communicative Effectiveness Index) in aphasic stroke patients. Disability and Rehabilitation 2005;27:287-291.

6. Bruce H, Dobkin MD. Rehabilitation after stroke. N Engl J Med 2005; 352:1677-1684.

7. Ortiz KZ. Afasia. In: Ortiz KZ, organizador. Distúrbios neurológicos adquiridos: linguagem e cognição. Barueri: Manole, 2005:47-64.

8. Mansur LL, Machado TH. Afasias: visão multidimensional da atuação do fonoaudiólogo. In: Ferreira LP, Lopes DMB, Limongi SCO. Tratado de fonoaudiologia. São Paulo: Roca, 2004:920-932.

9. Abo M, Senoo A, Watanabe S, et al. Language-related brain function during word repetition in post-stroke aphasics. Brain Imaging 2004;15:1891-1894.

10. Hummel FC, Cohen LG. Drivers of brain plasticity. Curr Opin Neurol 2005;18:667-674.

11. Musso M, Weiller C, Kiebel S, Müller SP, Bülau P, Rijntjes M. Trainiginduced brain plasticity in aphasia. Brain 1999;122:1781-1790.

12. Meinzer M, Elbert T, Wienbruch C, Djundja D, Barthel G, Rockstroh B. Intensive language training enhances brain plasticity in chronic aphasia. BMC Biology 2004;2:1741-1750.

13. Hochstenbach JB, Otter RD, Mulder TW. Cognitive recovery after stroke: a 2 follow-up. Arch Phys Med Rehabil 2003;84:1499-1504.

14. Mansur LL, Radanovic M, Ruegg D, Mendonça LIZ, Scaff M. Descriptive of 192 adults with speech and language disturbances. São Paulo Med J 2002;120:170-174.

15. Mansur LL, Radanovic M, Taquemori L, Greco L, Araújo GC. A study of the abilities in oral language comprehension of the Boston Dignostic Aphasia Examination - Portuguese version: a referene guide for the Brazilian population. Braz Med Biol Res 2005;38:277-292.

16. Mansur LL, Radanovic M, Araújo GC, Taquemori LY, Greco LL. Teste de nomeação de Boston: desempenho de uma população de São Paulo. Pró- Fono R Atual Cient 2006;18:13-20.

17. Santana BAS, Fukujima MM, Oliveira RMC. Características sócio-economicas de pacientes com acidente vascular cerebral. Arq Neuropsiquiatr 1996;53:427-432.

18. Connor LT, Obler LK, Tocco M, Fitzpatrick PM, Albert ML. Effect os socioeconomic status on aphasia severity and recovery. Brain Language 2001;78:254-257.

19. Chaves MLF. Acidente vascular encefálico: conceituação e fatores de risco. Rev Bras Hipertens 2000;7:372-382.

20. Zwann RA, Truitt TP. Smoking urges affect language processing. Exper Clin Psychophamacol 1998;6:325-330.

21. Kolk HHJ. Multiple route plasticity. Brain Language 2000;71:129-131.

22. Saur D, Lange R, Baumgaertner A, Schraknepper KW, Rijntjes WC. Dynamics of language reorganization after stroke. Brain 2006;129:1371-1384.

23. Heiss WD, Kessler J, Thiel A, Ghaemi M, Karbe H. Differential capacity of left and right hemispheric areas for compensation of poststroke aphasia. Ann Neurol 1999;45:430-438.

24. Johanson BB. Brain plasticity and stroke rehabilitation. Stroke 2000;31: 223-230.

25. Rijntjes M. Mechanisms of recovery instroke patients with hrmiparesis or aphasia: new insights, old questions and the meaning of therapies. Curr Opin Neurol 2006;19:76-83.

26 Thompson CK. The neurobiology of language recovery in aphasia. Brain Language 2000;71:245-248. 